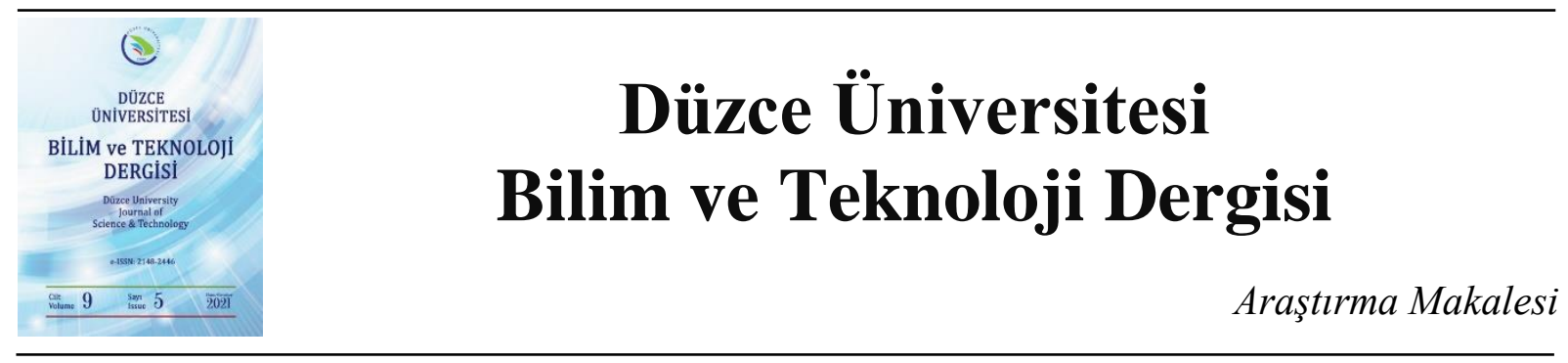

\title{
1923 Yılından Günümüze Apartman Tipi Konutlardaki Yatak Odası Gelişimi: Konya Örneği
}

\author{
Betül HATIPOĞLU ŞAHIN ${ }^{a}$,*, (D) Ayşenur DAĞ GÜRCAN ${ }^{\text {b }}$ \\ ${ }^{a}$ Mimarlık Bölümü, Güzel Sanatlar ve Tasarım Fakültesi, KTO Karatay Üniversitesi, Konya, TÜRKIYY \\ ${ }^{b}$ Mimarlık Bölümü, Güzel Sanatlar ve Tasarım Fakültesi, KTO Karatay Üniversitesi, Konya, TÜRKIYE \\ * Sorumlu yazarın e-posta adresi: betulhatip@gmail.com
}

DOI: 10.29130/dubited.868831

\begin{abstract}
$\underline{O ̈ Z}$
Cumhuriyetin kurulması ve sonrasında Sanayi Devriminin/endüstrileşmenin etkilerinin kentlerde hissedilmeye başlamasıyla konut sorunu ortaya çıkmıştır. Apartman tipi konut da en önemli konut sunum biçimlerinden bir tanesi olup, kentlerde kapladıkları alanlar dolayısıyla önem taşımaktadır. Çalışma alanı olarak seçilen Konya kenti de konut sorunundan etkilenmiştir. Bu nedenle farklı dönemlerde farklı tipte apartmanlar kentte yerini almıştır. Belirlenen dört dönem içinde üçer adet seçilen apartman tipi konutlarla, çalışmada on iki adet apartman mekân kurgusu bağlamında irdelenmiştir. Çalışmanın amacı ise; konutun en önemli birimlerinden olan, yatma-uyumadinlenme-giyinme bazen yıkanma gibi temel ihtiyaçları karşılayan "yatak odası" mekânının, belirlenen dönemler içindeki değişimini irdelemek olarak belirlenmiştir. İncelenen örneklerin planları üzerinden yapılan mekân okuması, erişim grafiği ve görünür alan analizleriyle yatak odası biriminin değişimi tartışmaya açılmak istenmiştir. Konutun en kişisel/mahrem mekânı olan yatak odasının değişimini tartışmaya açmak ve gelecek çalışmalara referans olmak amacıyla bu çalışmanın önemli olacağı öngörülmektedir.
\end{abstract}

Anahtar Kelimeler: Konut, Yatak odası, Apartman, Konya

\section{Bedroom Development in Apartment Types Houses since 1923: The Case of Konya}

\begin{abstract}
Especially after the establishment of the Republic, effects of the Industrial Revolution and industrialization began to be felt in the cities with the arising housing problem. Apartment type housing is also one of the most important forms of housing production, because of the areas it occupies in cities. Konya, which was chosen as the study area, was also affected by the housing problem. For this reason, different types of apartment buildings took place in the city in different periods. In the study, three apartments selected for each specified period. Totally twelve apartments were examined in the context of the spatial setup. The aim of the study has been determined as examining the change of the "bedroom" space, which is one of the most important units of the residence and meets the basic needs such as sleeping, resting, dressing, and sometimes washing, over the specified periods. The change of bedroom unit was asked to be discussed with the location reading, justified access graph and visible area analysis made on the plans of these structures. It is anticipated that this study will be important in order to open the discussion of the change of the bedroom, which is the most personal space of the house, and to reference future studies.
\end{abstract}

Keywords:Housing, Bedroom, Apartment, Konya

Geliş: 27/01/2021, Düzeltme:26/05/2021, Kabul: 02/06/2021 


\section{GIRIS}

Tarihi Roma'daki İnsula konutlarına kadar uzanan apartman yapıları kent dokusunda önemli bir yer oluşturmaktadır. Sıkışık kentlerde çok katlı barınma imkânı tanımasından ötürü yüzyıllardır kullanılagelen bir yapı türü olmuştur. Ancak bugünkü anlamıyla bakacak olduğumuzda apartman 18. Yüzyılda Paris'te ve diğer büyük Avrupa şehirlerinde orta sınıf kiracılar için ortaya çıkmıştır [1]. Bu dönem Avrupa'sında kentlere olan göç dalgası beraberinde, yüksek arsa maliyetini de getirmiş olup bu maliyeti karşılayamayan orta sınıf için apartman, kentlerin vazgeçilmezi olmuştur [2]. Türkçeye de Fransızca appartement kelimesinden geçmiş olan kavram; batı kökenli dillerde bina içindeki bağımsız birim olan tek bir daireyi tanımlarken $[3,4]$ Türkçede bu konut birimlerinin tümünü ifade eden bina anlamında kullanılmaktadır. Türkiye'de yer alan apartman tipi konutlar, 19. Yüzyıl Osmanlısı ve Erken Cumhuriyet döneminde üst-orta gelir grubuna yönelik bir konut üretim biçimiyken, zaman içerisinde hızla artan nüfustan dolayı kentlerde beliren konut sorununa çözüm olma noktasında karşımıza çıkmaktadır. Bu bağlamda toplu konut, gökdelen, rezidans gibi farklı konut biçimleriyle kentsel dokuda önemli bir yer tutmaktadır. [5]. Bu çalışma; apartman tipi konutun Türkiye'deki gelişimini dönemsel olarak irdeleyerek, apartmanın Cumhuriyet döneminden günümüze nasıl bir gelişim gösterdiğini değerlendirmeyi amaçlamaktadır. Aynı zamanda çalışmanın temel kurgusunu oluşturan ve araştırmayı özgünleştiren kısım, konutun en mahrem ve özel alanı olan "yatak odası" biriminin mekânsal gelişim ve değişiminin, dönemler üzerinden sınıflandırılarak yerel ölçekte irdelenmesi olmuştur.

\section{A. TÜRKIYE'DE KONUT POLITIKALARI}

Apartman tipi yapıların Türkiye sınırları içerisindeki ilk örnekleri Osmanlı dönemine rastlamaktadır. Osmanlı'da kolektif yaşamın ilk temsilcisi olarak görülen, 15. Yüzyılda büyük kentlerde vakıflara ait kiralık odaların, 18. yüzyılda ise her katı bağımsız ve mutfağı, helası ayrı olan konut birimlerinin varlığı bilinse de günümüze ulaşamamıştır [2]. Batılı anlamda apartman ise 19. Yüzyıl'ın ikinci yarısından sonra başkent İstanbul'da, Müslümanların yanında daha çok azınlıklar, Levantenler ve elçilik mensuplarının yaşadığı çok kültürlü bir yerleşim olan Galata-Beyoğlu'nda görülmeye başlanmıştır [6]. Bölgedeki apartmanların mimarları ve ilk sakinleri yabancı kökenli olup, batılılaşma hareketleriyle birlikte Müslüman kesim de buradaki apartman hayatına dahil olmuştur. Fakat apartman hayatına dahil olan bu kesim batı kültürünü benimsemiş ve refah düzeyi yüksek Osmanlı elitlerinden oluşmaktaydı. Bu sürecin devamında Taksim, Sıraselviler, Cihangir, Şişli, Nişantaşı ve Teşvikiye gibi semtlerde tarihi konaklar yerini apartmanlara bırakmıştır. Ancak kat mülkiyeti kavramı henüz yasallaşmadığından, ayrıca Müslüman ailelerin güvenlik ve mahremiyet unsurlarına gösterdiği hassasiyetten ötürü bu apartmanlar yalnızca akrabaların bir arada oturduğu konutlar haline gelmiştir [7]. Müstakil ve çoğunlukla bahçe içerisinde yer alan, ahşap karkas sisteme ve sofalı plana sahip geleneksel Osmanlı konutundan farklılaşan bu apartmanlar cadde üstünde konumlanan, 5-6 katlı, tuğladan örülmüş yığma yapılardı. Ayrıca bu yeni yapı tipolojisinde sofa mekânı farklı olarak yorumlanmıştır. Sedat Hakkı Eldem'in Türk Evi Plan Tipleri çalışmasında sofasız, dış, iç ve orta sofalı olarak sınıflandırdığ 1 Osmanlı konutu, son dönem İstanbul konaklarında orta sofalı tipte geliş̧im göstermiştir [8]. Orta sofalı şemada, sofa merkezli odalara dağılım gösteren kurgu bu yapılarda farklılaşmış, sofa-salon mekânı ortaya çıkmış ya da sofa küçülerek giriş holüne dönüşmüştür [9]. Batılı yaşamı benimsemiş Osmanlı bürokrat ve burjuva kesiminin yaşadığı bu konutlarda, iç mekân organizasyonu da Avrupalı mobilya anlayışı ile düzenlenmiştir. Aynı zaman da bu organizasyon ve mobilya tercihi yatak odası, salon gibi özelleşmiş mekânları da beraberinde getirmiş ve bu birimler apartman plan tipolojisinde yerini almıştır. Demirarslan (2006), bu durumu "Yer sofrasından masaya, döşekten karyolaya, sedir ve minderden koltuk ve iskemleye, "baş oda"dan "salon"a, "sofa"dan "koridor"a, geleneksel konuttan apartmanlaşmaya varan bir kimlik dönüşümü" olarak ifade etmiştir [10]. Osmanlı'nın son döneminde gerçekleşmeye başlayan bu kimlik dönüşümü özellikle başkent İstanbul'da etkili olmuş, yaşamın her alanında batı etkisi gözlenmiştir. Bu sürecin devamında Cumhuriyetin ilanıyla birlikte batılılaşma faaliyetleri daha çok hız kazanmış fakat dönemin atılımları İstanbul'dan ziyade Ankara üzerinde gerçekleşmiş̧ir. 
Türkiye'deki Cumhuriyet sonrası apartmanlaşmanın gelişimini tartışmaya açmadan önce, ülkemizdeki konut politikaları hakkında genel bir çerçeve çizmek doğru olacaktır. Çalışma kapsamında konut politikaları ve çalışmanın ana kurgusunu oluşturan apartman kavramının gelişim süreci açıklanacaktır. $\mathrm{Bu}$ noktada incelenen literatür araştırmaları ışığında Akalın'ın yapmış olduğu sınıflandırma çalışma kapsamında kullanılmıştır. Akalın bu dört dönemi:

- 1923-1950 Yılları Arasındaki Dönemi Ulus Devlet Anlayışı ve Memur Merkezli Konut Politikalar1

- 1950-1980 Arası: Savaş Sonrası Planlı Dönem

- 1980-2002 Yılları Arası Liberal Dönem

- 2002 Sonrası: Adalet ve Kalkınma Partisi Dönemi olarak sınıflandırmıştır [11].

1923-1950 yılları arası Cumhuriyetin ilan edilmesiyle birlikte yeni başkentinin imar ve iskan edilmesi sonrasında, memur konutlarının üretilmesi açısından önem taşımaktadır. 1950-1980 yılları arası; kentleşmenin hızla kentlerde etkisinin görüldüğü, kırdan kente durmaksızın bir göç dalgasının yaşandığı ve bu noktada kentlerin yapısının hızla değiştiği bir dönem olmasının getirisi olarak çok çeşitli konut politikalarının yürürlüğe girmesi nedeniyle önemlidir. 1980-2002 yılları arası liberal politikaların toplum yapısına etki etmesiyle konut politikalarının da değiştiği bir dönem olarak değerlendirilmektedir. 2002 yılından günümüze olan süreç ise özellikle merkezi otoritenin değişmesiyle TOKİ ve yerel yönetimlere verilen yetkilerle konut üretiminde devlet kurumunun başrole geçmesi açısından önem kazanmıştır.

1923-1950 yılları arası dönemin en önemli özelliği Sey’in de tariflediği gibi savaştan yeni çıkmış bir ülkenin kaynaklarındaki yetersizlikle birlikte yeni sanayileşmeye başlayan kentler ve kırsal alandaki insanların yoğunluğudur [12]. Bu nedenle genel olarak bakıldığında kaynakların sanayileşmeye aktarıldığını söylemek mümkündür. Bu dönemin konut politikaları bağlamında özelleşmesini sağlayan en önemli gelişme Ankara'nın başkent olmasıdır. Bu dönemde özellikle Ankara'nın imarıyla ilgili çeşitli gelişmelerin olduğunu söylemek mümkündür. Özellikle Ankara gelişmesi bir plana bağlı ilk kent oluşuyla oldukça önemli bir noktadadır. 1932 yılında Jansen Planının yürürlüğe girmesinden önce günümüzde Yenişehir olarak bilinen semtin kurulması, arsa kamulaştırılması yoluyla olmuştur. Ayrıca dönemde kentte hızla artan memur nüfusu nedeniyle konut sorununa devlet bütçesinin bir bölümünden memur konutlarına ödenek ayrılması yoluyla çözüm aranmıştır. Bu noktada Paul Bonatz'ın tasarlamış olduğu Saraçoğlu Mahallesi önemli bir adım teşkil etmektedir. 1926 yılında kurulan, ucuz konut için kredi vermek, bina yapıp satmak gibi görevleri bulunan Emlak ve Eytam Bankası'nın (1946 tarihli yasayla görevleri ve sermayesi artırılarak ismi Emlak Kredi Bankası'na dönüştürülmüştür) vermiş olduğu konut kredisiyle Saraçoğlu devlet lojmanları 1944-45 yıllarında inşa edilmiştir [13]. Özellikle sosyal yapılar ve açık alanlarla bir mahalle fikri kurma amacıyla yola çıkan planlama [14], üst düzey bürokratlar için kiraya verilmiştir [15]. Daha önce inşa edilen müstakil evlerden oluşan Bahçelievler yerleşkesine alternatif bir öneri olan bu yerleşke, sekiz farklı konut tipinden oluşan, 2-3 katlı çok aileli konut blokları olarak düşünülmüştür [16]. Saraçoğlu apartmanları, cephede yer alan çıkmaları, ahşap kafesli korkuluklara sahip balkonları, plan kurgusundaki odaların hol olarak adlandırılan sofa benzeri merkezi mekâna açılmaları ile modern milli mimari örneği olarak döneminde yankı uyandırmıştır.

Bu dönemde aynı zamanda bireysel konut üretimi de başlamıştır. Tekeli bireysel konut üretimini "Yavaş bir kentleşme, kentsel arsaların henüz spekülatif değer kazanmaması, dolayısıyla konut maliyeti içinde arsa maliyetinin düşük olması, yerel yönetimlerin yavaş olan kentleşme hızına paralel olarak yeterli alanlar planlayabilmesi ve kentsel altyapı sağlamakta önemli sıkıntılarla karşılaşılmaması bu tür üretimin toplumsal gereksinmeyi karşılayabilmesi için gerekli koşulları oluşturuyor." [17] şeklinde açıklamıştır. 1930-40 yılları arasında görülen özel mülkiyete ait bu konutlar, yüksek gelirli mal sahipleri tarafından apartman dairelerini kiraya vermek amaçlı yaptırılmalarından ötürü "kira evleri" olarak adlandırılmış [5], dönemin başlıca mimarlık dergisi olan Mimar/Arkitekt'de de sıkça yer almışlardır. Bu dönemin konut mimarlığına ilişkin önemli metinsel kaynak ve proje arşivi sunan Arkitekt dergisi 1931 yılında, Zeki Sayar öncülüğünde kurulmuş, 50 yıl kadar yayın hayatına devam etmiştir. Cumhuriyetin ve Kemalist ideolojilerin çizgisine bağlı kalan dergi, dünyadaki gelişmelerden mimarlık çevresini haberdar etmenin yanı sıra, o sırada sayıları çok az olan ve Türkiye'deki uygulamalarda yabancı 
mimarların gerisine itilme durumunda kalan Türk mimarların, projelerine öncelik tanımak gibi bir misyon da edinmiş̧ir [18]. Dönemde etkin rol oynayan, Almanca konuşan ülkelerden misafir olarak ülkeye gelen yabancı mimarlar cumhuriyetin kamu binalarını modern mimarlık ilkelerine bağlı kalarak tasarlamışlardır. Aynı zamanda akademisyenlik görevini de devam ettiren Clemens Holzmeister, Bruno Taut, Ernst Arnold Egli, Paul Bonatz gibi mimarların yetiştirdiği Türk mimarlar bu ekole sadık kalmış, dönemde "kübik mimari/Ankara Kübiği" olarak adlandırılan "asri mimarlık" örneklerini tasarlamışlardır. Kamu yapılarının ihaleleri yabancı mimarlara gidince yeni yetişen yerli mimarlar müstakil ve apartman konut tasarımına yönelmişlerdir. Avrupa etkilerinin yerel teknik imkanlar ile birleştiği bu konutlar Bozdoğan'ın (2002) ifadesiyle kıyıda kalmış modernizm olarak adlandırılan, düz çatıları, yuvarlak köşeleri, sürekli balkonları, dairesel pencereleri ve kübik formları ile kolay tanınabilen bir estetik oluşturmaktaydı [19]. Bir önceki dönemde İstanbul, Galata'da yer alan apartmanlara göre daha küçük ölçekli, daha yalın ve süsleme unsurlarından arındırılmış olan bu apartmanlar değişen yaşam standartları ve teknolojiyle birlikte çekirdek aileye uygun ölçekte tasarlanmıştır. $\mathrm{Bu}$ apartmanlar genellikle bodrum üzerine üç kat ve çatı katından oluşmaktaydı [20]. Aynı zamanda cephede yatay hatların vurgulandığ çizgiler barındıran, kübik formlu bazen de kübik ve yarı dairesel köşeli formların birlikte yer aldığı örneklerdir. Bu konutlar kâgir yığma veya betonarme taşıyıcı sistemle kurgulanmıştır. Ayrıca kaloriferin de konutlarda yer almasıyla birlikte plan kurgusu; merkezi hole/sofaya açılan veya koridora sıralanmış odalardan oluşmaktadır [5]. Aslanoğlu'nun [20] ifadesiyle bu dönemde her katta yer alan ikişer daire genellikle üç oda ve bir sofadan meydana gelmektedir. Çoğunlukla bu tip konutlar Batılı yaşamı benimseyen üst düzey memur veya orta üst sınıfa yönelik inşa edilmiştir. Bu konutlarda özelleşmiş odalar görülmeye başlanırken geleneksel Türk evinin çok fonksiyonlu olan odası ve iç mekân organizasyonu artık kaybolmuştur. Türk odasının sabit ve geleneksel donatı anlayışı, Bauhaus ekolünü takip eden çağdaş malzemelerden üretilen modern mobilyalara yerini bırakmıştır. Ancak bu modernist tutumların yanında, 1930ların sonuna doğru başlayan milli mimari arayış çerçevesinde sofa oluşumu çoğu örnekte hol adıyla devam etmiş, yüklük, sandık odası gibi birimler bazı örneklerde yerini almış, mutfaklar ise kadının mahremiyeti ile ilişkili olarak girişten uzak noktalarda konumlanmıştır. Bu dönemde holün gerekliliği mimari metinlerde vurgulanmıştır. Konuta gelen misafirin kapıdan girer girmez holde kabul edilmesi ve misafirin evin içinde gezmesinin, toplu olmayan odaları ve yatak odalarına açılan koridorları görmesinin doğru olmadığ1 yer almıştır [21]. Bu bağlamda apartman özelinde konu irdelenecek olursa bu geçiş dönemini yansıtan farklı apartman tipoloji denemelerinin olduğu görülmektedir. İlk dönem örneklerinde uluslararası üslubun içselleştirilmeden biçimsel yönden ele alınış1 30'lu yılların sonunda bu yapılara eleştiri oklarının yönelmesine neden olmuştur. Sedat Hakkı Eldem öncülüğünde geleneksel Türk evi, Egli önderliğinde ise Anadolu'nun yerel ve eski ev mimarisi etüd edilmiş, buradan hareketle modern mimarlığın Eldem'in ifadesi ile milli, Egli’nin ifadesi ile muhit'e göre karakter kazandığında başarılı olabileceği görüşü öne sürülmüştür [16]. Bu bağlamda Saraçoğlu apartmanlarında olduğu gibi modern ve geleneksel unsurları birlikte barındıran üslup 194050'ler boyunca cephede ve/veya planimetride kendini göstermiştir. Ancak gerek uluslararası gerek milli çizgiler taşıyan bu modern konutlar toplumun sadece üst orta gelir grubuna yönelik bir barınma şeklini ifade etmekteydi. 1930 ve 4011 yıllarda bu üst sınıf kentli, apartmanlaşma olgusunu başlatmış ve apartmanda oturmak bir prestij unsuru haline gelmiştir. Tanyeli'nin [22] ifadesiyle "Türk apartmanlaşmasında Modernite'ye ilişkin olan taraf, ülkeye giren yeni mimari repertuardan çok, apartman aracılı̆̆ıyla zevkini ve modernliğini gösteren yeni insan” olmuştur. Apartmanın modern bir temsil aracına dönüşmesi, ülkenin çok küçük bir grubunun bu yaşam tarzına entegre olmuş olması cumhuriyetin ilkeleri ile ters düşse de işçi ve orta sınıf için küçük ve standart konut üretimini karşılayacak ekonomik ve teknik imkan yeterli değildi. 1950'lerden sonra köyden kente göçlerin artmas1 ve gereken hesaplı konut stokunun sağlanamaması sonucunda ilerleyen dönemde bu eksikliğin yerini, gecekondulaşma dolduracaktı [16].

1950-1980 yılları arası dönem, önceki döneme kıyasla gecekondulaşma probleminin tüm ülkeye yayıldığı, yap-satçılık, kooperatifçiliğin hızla arttığ 1 , toplu konut sunum biçiminin ise ilk örneklerinin görüldüğü bir dönem olması açısından, apartman özelinde çok önemlidir. Bu dönemde 2. Dünya savaşının bitimiyle tüm dünyada ve Türkiye'de yeniden artan sanayileşme hareketleri, ülkede köyden kente göçün yoğunlaşmasına sebep olmuştur. Bu da beraberinde göç eden kesimin barınma sorununa neden olmuş ve gecekondulaşma süreci hızlanmıştır. Çoban bu dönemi "emekçinin barınma sorunu" 
olarak nitelendirmekte olup, gecekondulaşmayı engelleme ve kamu arsalarının satılarak konut üretimini artırmayı hedefleyen yasaların amacına ulaşamadığını belirtmiştir [13]. Bu bağlamda dönemde ortaya çıkan ve apartmanlaşmanın gelişiminde önemli katkıları olan üretim biçimi yap-satçılıktır. 1954 tarihli Tapu Kanunu'nda yapılan değişikliklerle birlikte tek parseldeki bina üzerinden birden çok kişinin irtifak hakkı kurmasına olanak tanınması ve devamında 1965 'te çıkan kat mülkiyeti kanunu yap-satçılığın doğmasında etkili olmuştur. Tekeli yap-satçılığı; orta sınıfın tek parsel üzerinde ev yapabilecek maddi gücü bulamayışından dolayı arsa ücretinin bölüşülerek mülk sahibi olma durumu olarak özetlemektedir [17]. Bu noktada yapsatçı üretim; eski az katlı bahçeli ev sahiplerinden daire karşıllı̆ı arsa temini yapılması ve alanın apartmana dönüştürülmesi, kalan dairelerin de satılıp müteahhitlerin neredeyse hiç sermaye koymadan ortaya koydukları bir sistem halini almıştır [6]. Ancak yüksek kâr amacı güdülen bu sistemle estetik ve yapım kalitesinden ödün verilmiş olup, konut mimarisinde monotonluk ve kimlik kaybının ortaya çıkması kentlerin doku ve görünümünü olumsuz etkilemiştir [23]. Bu dönemdeki bir diğer konut üretim biçimi ise kooperatifçiliktir. Özellikle işçi ve memurlardan oluşan grupların kooperatifler kurarak apartman sahibi olmaya yönelik girişimleri mevcuttur. Bu kooperatiflerin kent dışında ucuz arsalarda kurulmasıyla, toplu apartman yapımları görülmektedir [24]. Özetle bu dönemde 1950 öncesi modern mimarlık çizgilerinin vurgulandığı, kübik, küçük ölçekli, az katlı yapıların yerini kooperatifler ve Emlak Bankası tarafından üretilen savaş sonrası Avrupa'daki apartmanlaşma tipolojisinin benimsendiği, birbirini tekrar eden blok apartman yerleşmeleri almış, yap-sat düzeniyle birlikte kat yükseklikleri de artmıştır [5]. Bu dönemle birlikte apartman Türkiye için temel konut normuna dönüşmüş, beton bloklardaki standart apartman hayatı önceki dönemin kübik apartmanlarından farklılaşmıştır. $\mathrm{Bu}$ apartmanlara misafir odası-oturma odası ayrımı, ailenin yemek odası yerine mutfakta yemek yemesi, batı tarzı tuvalet-banyonun yanına alaturka tuvalet eklenmesi gibi geleneksel ev hayatının birçok yönü dahil edilmiştir [19]. Daha önce üst ve orta sınıfa hitap eden apartman, bu dönemde alt gelir grubunun da dahil olduğu barınma şekli olmuştur. Bu nedenle evlerin metrekareleri küçülmüş temel işlevleri karşılayan iki oda, salon, mutfak, wc ve banyodan oluşan standart bir konut tipi benimsenmiştir. Ancak 1965 Kat Mülkiyeti Yasası'ndan önce gerçekleştirilen, ailenin yaşam şekli ve gereksinimlerine uygun tasarlanmış apartmanlarda üç veya iki adetten oluşan dar holler ile konut içine dağılım görülmektedir. Bu dönemde kullanıcı talepli daha özelleşmiş mekânlar olarak hizmetçi odası, ayrı bir servis girişi, sandık odası, kiler, yüklük, vestiyer, çalışma odası ve mutfakların dar olmasından ötürü ayrı bir yemek odası konut planlarında karşımıza çıkmaktadır [25]. Bu dönemin sonlarına doğru konut planlarında girişin yer aldığı antre önceki dönemdeki sofaya göre küçülmüsstür. $\mathrm{Bu}$ antreye bağlanan yatak odası/ları ve banyonun açıldığı gece holü oluşumu da görülmektedir. Ayrıca dönemdeki ilk örneklerde yatak odalarına yüklük donatı olarak eklenmiş, dönemin sonlarına doğru ise hâkim mobilya anlayışı olan yatak odası takımlarının içerisinde yer alan gardıroba yerini bırakmıştır.

1980-2002 yılları arası dönem Yenice tarafindan "Liberal-imar afları dönemi" olarak adlandırılmaktadır. Bu dönemde özellikle gecekondu ve kaçak yapıların ruhsatlandırılmasıyla ilgili uygulamalar görülmektedir. Gecekondu alanlarının apartman türü konuta dönüşmesini amaçlayan yasalar çıkarılmıştır [26]. Ayrıca dönemdeki en önemli gelişme 1984 tarihinde Toplu Konut ve Kamu Ortaklığı İdaresi'nin kurulmasıdır. Keleş'e göre 2487 sayılı Toplu Konut Kanunu bireysel konut üretimi yerine geniş çaplı üretimini özendirmektedir [15]. Bu bağlamda alt ve orta gelir grubunun konut edinmesine yönelik kolaylık sağlanmıştır. Ayrıca konut kooperatifleri de teşvik edilip, farklı fonlarlar konut edindirmeye destek olunma amacı güdülmüştür. Bu dönemde bir başka konut tipi ise genel olarak üst gelir grubu kullanıcıların tercih ettiği, kent dışında ya da çeperde kurulu, kendi kendine yetebilen "kapalı site" olarak adlandırılan yapıların ilk örnekleri görülmüştür [27]. Konutla birlikte bir yaşam tarzının da satıldığı ilk örnekler; İstanbul'da Kemer Country ve Alkent 2000 kapalı siteleridir [28]. Yine bu dönemde bir diğer barınma biçimi alternatifi ise ilk örnekleri İstanbul'da görülen; kapalı sitelerin kent dışındaki yaşam biçimine alternatif, kent merkezinde inşa edilen "rezidans"lardır. Kent merkezinde küçük parsellerde, çok katlı binalar şeklinde inşa edilen konutlar kullanıcısına birçok farklı sosyalleşme mekânlarını sunmaktadır.

2002 yılı sonrası dönemde; merkezi yönetimin değişip, Acil eylem planının yürürlüğü girmesiyle birlikte TOKİ'nin etkin olarak konut üretimi yapması başlamıştır. Özellikle alt ve orta gelir grubu bireyleri konut edindirmeye yönelik yapılan konut seferberliği sayesinde Kurum, inşaat sektörünün baş aktörü haline gelmiştir. $\mathrm{O}$ tarihten günümüze olan süreçte yaklaşık 940 bin konut üretilmiştir. $\mathrm{Bu}$ 
dönemde Türkiye'de konut oldukça çeşitli varyasyonlarda kendini göstermiş bir yanda yasallaşan gecekondular, bir tarafta tekil apartmanlar diğer tarafta blok apartmanlar, daha çok üst orta sınıfa yönelik toplu konutlar görülmektedir. 90'lar ile büyük şehirlerde başlayan fakat 2000'lerden sonra Anadolu'da da gelişme bulan kent çeperinde izole edilmiş bahçeli villalardan oluşan sitelerde yaşayan yeni bir üst sınıf yaşamı ve devamında yer alan kapalı siteler, yine üst ve üst orta sınıf için kent merkezinde yapılmış rezidanslar, çekirdek aileden ayrılan gençler, tek başına yaşayan fertlere hitap eden stüdyo apartmanlar [29], alt gelir grubu için üretilen toplu konutlar, kentsel dönüşümle gecekondu bölgelerine yerel yönetimlerce yapılan blok apartmanlar olarak yerini almıştır. İçinde bulunduğumuz bu dönemde konut yelpazesindeki çeşitlilik apartman tipolojisine de yansımıştır. Tekil birey veya çiftler için tasarlanan $1+1,1+0$ stüdyo dairelerin yanında standartlaşmış $2+1,3+1$ daire uygulamaları devam etmekte, çok çocuklu ailelerin ya da üst orta sınıfın tercih ettiği 4-5 odalı dairelere kadar büyümenin de görüldüğü gözlemlenmektedir. Lüks daire kapsamı altında emlak piyasasında yer eden 4 veya 5 odaya sahip bu evlerde önceki yıllarda görülen özelleşmiş mekânlar yeniden gündeme gelmiştir. $\mathrm{Bu}$ dairelerde geleneksel evlerde görülen gömme dolap/yüklük geleneği giyinme odasıyla veya sabit dolaplarla yeniden gündeme gelmiş, çamaşır odası, ütü odası, kiler, hobi odası, banyolu misafir yatak odası gibi çeşitli özelleşmiş mekânlar konut birimine eklenmiştir [7]. Ebeveyn yatak odası diğer yatak odalarından büyüklük ve donatı bakımından ayrılmış, giyinme odası ve özel banyosuyla mekân farklılaşmıştır. Bu konutlarda daire başına ayrılan birden fazla araç yeri, kapalı otopark ve otoparktan direkt daireye çıkılması gibi imkanlar kullanıcı için önemli bir tercih sebebi olmuştur.

\section{MATERYAL-METOT}

Çalışma kapsamında seçilen Konya kenti; Türkiye'nin yüzölçümü bakımından en büyük kenti olmasının yanı sıra aynı zamanda nüfus büyüklüğü açısından da 7. büyük kentidir. Genel olarak bakıldığında bir tarım kenti olmasına karşın, 1950'li yıllardan itibaren hızla nüfusu artmış, sanayileşme kenti de etkisi altına almıştır. Bu bağlamda planlı bir kentleşmeye sahip olsa da süregelen yıllar boyunca değişen yaşam koşulları, ekonomik durum, farklı konut politikaları nedeniyle kentin yapısı değişmiş̧ir. Bu çalışmada; yukarıda tariflenen farklı konut politikalarının şekillendirmiş olduğu, apartman tipi özelinde mekân organizasyonun özellikle yatak odaları ve ona bağlı sabit donatı elemanlarının nasıl bir değişim gösterdiğini tespit etmek amaçlanmıştır. Bu bağlamda yukarıda ifade edilen 4 dönem içerisinde, çalışma kapsamında incelenecek apartman örnekleri her dönem için üçer yapı olmak üzere gruplandırılmıştır. Örnekler belirlenirken konutun -yapım yılı esas alınarak- ait olduğu dönemin özelliklerini ve mimari karakterini yansıtmasına dikkat edilmiştir. Dönem özelliklerini taşıma unsuru ele alınırken konutun yapım hikayesi göz önünde bulundurulmuş, kira evi, yap-sat, kooperatif, kapalı site, toplu konut gibi her dönemde farklılaşan ağırlıklı konut üretim biçimine göre örnekler belirlenmiştir. Konutun plan kurgusu, kütle ve cephe biçimlenişi ise dönemin mimari karakterini taşıma unsuru kapsamında dikkat edilen parametreler olmuştur. Bunun yanında apartman yapılarının, Konya kentinin gelişiminde önemli olan caddeler üzerinde veya genişleyen kentin yeni yerleşim bölgelerinde konumlanma durumu göz önünde bulundurulmuştur. Mevlana Caddesi, Alaaddin Bulvarı, İstasyon Caddesi, Nalçacı Caddesi üzerinde veya civarında konumlanan ilk üç dönem örnekleri kent merkezine yakın noktalarda yer alırken son dönem örnekler büyüyen kentin çeperlerinde yer alan yeni konut üretim alanlarında konumlanmaktadır. Söz konusu yapıların kent hafızasında yer etme durumu (ilk apartman, ilk kooperatif, ilk çok daireli ve yüksek katlı konutlar, dönemin ilk lüks apartmanı) da ayrıca göz önüne alınmıştır. Örneklerin planlarına arşiv ve konut literatürü üzerinden erişilebilirliği de bir diğer belirleyici nitelik olmuştur. Söz konusu araştırmanın pandemi döneminde yapılması konut içlerine girilmesine imkân tanıyamamıştır. Araştırma alanı belirlendikten sonra yerinde inceleme yapılmış, planlar bilgisayar ortamında yeniden çizilmiş ve plan kurgusu okunmuştur. Daha sonra bu apartmanların mekân organizasyonları, girişten görünürlük analizleri, erişim grafikleri ve tüm konut içerisindeki yatak odasının ve sabit donatıların kapladıkları alanlar ortaya konmuştur. İncelenen yapılara ait planların morfolojik özelliklerini tespit etmek adına Hillier ve Hanson'un 1984'te mekân dizim kuramı ve yöntemini açıkladıkları çalışmalarında yer alan mekânsal konfigürasyonu nicel olarak ifade etmek için tanımladıkları geçiş grafiği yönteminden faydalanılmıştır [30]. Konutun erişim grafiği ve dallanma yapısı tespit edilirken yatak odası ve destek birimleri mekânlarının ise mekân derinlik derecesine 
bakılmıştır. Ancak graf yönteminde yer alan bütünleşme ve derinlik değerleri burada hesaplanmamış olup yalnızca sistemin dizimsel yapısına bakılarak değerlendirme yapılmıştır. Mekânsal analiz olarak görünür alan yöntemini ilk ortaya atan Benedikt, mekân içerisinde belirlenen bir nokta üzerinden görünen tüm noktaların tamamı olarak isovistleri/görünür alanı tanımlanmıştır [31]. Küçük ölçekli çevrelerin mekânsal analizi için önerilen isovistlere bu çalışmada başvurulmuştur. Konutun girişi bakış noktası olarak tanımlanmış buradan konutun içerisine bakılarak görünür alanlar taranmıştır. Görünürlük analizi yöntemi ile konutun en özel mekânı olarak kabul edilen yatak odasının mahremiyet derecesi belirlenmeye çalışılmıştır. Bu çalışmada aynı zamanda yatak odalarına bağlı sabit yüklük, sandık odası gibi elemanların süreç içerisinde hangi mekân ve donatılara evrildiğini ortaya koymak amaçlanmıştır. Genel bir bakış açısıyla özellikle konutun en önemli ve mahrem mekânı olan yatak odasının süreç boyunca değişiminin irdelenmiş olduğu bu çalışmanın, ilerleyen çalışmalar için bir referans kaynağı olması umulmaktadır.

\section{A. ALAN ÇALIŞMASI: KONYA}

Cumhuriyetin başkenti Ankara 1920'lerden sonra yeniden imar edilmiş, cumhuriyet ilkelerine bağl1 yeni devleti temsil eden yeni bir kent kurulmuştur. Bu kentin yapılaşma süreci ve apartmanın da gelişimi diğer Anadolu kentlerine de örnek olmuştur. Modernleşme ile bağdaştırılan kübik apartmanlar, Anadolu kentlerinde çoğunlukla köyden kente göçlerin arttığ 1 1950'lerden sonra görülmeye başlanmıştır. Konya da bu gelişim sürecine ayak uydurmuştur. Konya kentinde apartmanlaşma 1937 yılında yapılan Hayat apartmanı istisna kabul edilirse 50'li yıllarda başlamıştır. 50'li yıllardan önce geleneksel konut üretimi devam etmektedir. Kentte büyük ölçüde yer alan bu geleneksel yapılar Konya yöresine özgü kerpiç malzemeden inşa edilen avlulu/hayatlı, mabeyinli, tek katlı, toprak damlı içe kapalı yapılardı [32-33]. 19. Yüzyıldan itibaren ise batı etkisinde gelişen, başkent İstanbul'daki köşkleri örnek alan iç veya orta sofalı, iki ya da üç katlı, cumbalı, kerpiç/taş yığma veya ahşap karkas iskeletli, kırma çatılı olan Osmanlı konutları görülmeye başlanmış, dönemin kentin ileri gelen sakinleri tarafından kent merkezinde inşa ettirilmişlerdir [34-35].

Kentin ilk apartman yapısı olan Hayat apartmanı Ankara ve İstanbul'da görülen kira evlerinin bir benzedir. Kentin önemli bir aksı olan Mevlâna caddesinde konumlanan yapı, zemin üzerine üç katlı, zemin katta dükkanların yer aldığ 1 üst katlarda ise ikişer dairenin konumlandığı, betonarme bir yapı olup kübik apartman imgesini taşımaktadır. Bir köşede yer alan yarı dairesel formun kübik yap1 ile bütünleşmesi, yatay çizgilerin pencereler ile vurgulaması dönemin özelliklerini yansıtmaktadır. 1950'lerden sonra kentte yükselen diğer apartman yapıları öncü yap1 olan Hayat apartmanını izler niteliktedir. Kentte yer alan bu ilk apartman örnekleri geleneksel şemaya bağlı kalan yapılardır. $\mathrm{Bu}$ yapılarda sofa/hol oluşumu görülmekte hem dönemin karakterine hem de mabeynli evlere öykünülmektedir. Ulusoy'a göre mutfak ve hela ise hem geleneksel alışkanlıklardan hem de tesisat birliği açısından yan yana olup, sofadan ve yaşama mekânlarından en uzak noktada konumlanmıştır [34].

1960'lı yıllarda kat mülkiyeti yasası ile ülkede yoğunlaşan apartmanlaşma faaliyetleri Konya'da da izlenmektedir. Bu dönemde kent çeperlerine doğru yayılmalar başlamış, Nalçacı caddesi gibi yeni caddeler açılmış, önceki örneklere göre daha yüksek katlı apartmanlar kooperatifler yoluyla bu bölgelerde inşa edilmiştir. Bu dönemde Konya'da Vedat Dalokay, Şevki Vanlı, Coşkun-Filiz Erkal gibi dönemin tanınmış mimarları kamu ve sivil mimari alanında eserler vermiştir. Dönemdeki önemli konut yapılarına Yeşil Meram Sitesi, Anıt Apartmanı, Horozluhan Apartmanı, Ankara Apartmanı örnek gösterilebilmektedir. 1970'ler ile birlikte özellikle Nalçacı caddesi üzerinde konumlanan yüksek katlı apartmanlar bir bir boy göstermeye başlamıştır. Bu konutların büyük çoğunluğu orta sınıfa yönelik olup, memur ve esnaf gruplarının kooperatifler yoluyla inşa ettirdiği yapılardır. $\mathrm{Bu}$ dönem yapılarına bakıldığında metrekarelerin küçüldüğü, sofa/hol mekânının yerini antreye bıraktığı, gece holünün küçülerek ebeveyn yatak odası ve banyoya açıldığı ayrıca yatak odalarındaki yüklük geleneğinin devam ettiği gözlemlenmektedir. Bunun yanından dönemin modası olan salon salamanje olarak adlandırılan oturma ve misafir bölümünden oluşan iki mekânla salon uygulaması görülmektedir. 1985 yılından sonra site tipli lüks apartmanlar ilgi görmeye başlamış [34], 1990’lı yıllar ile Meram ilçesinde siteler boy 
göstermeye başlamıştır. Üst ve üst orta gelir grubu için bu konutlarda yaşamak bir prestij olarak algılanmıştır. Bunun yanında kentte apartmanlaşma devam etmiş kent merkezinde konumlanan Köşk apartmanı yine üst orta gelir grubuna hitap eden bir yapı olarak değerlendirilmiştir.

Konya kentinde alt gelir grubunun konut sorununa ilişkin çözümler ise 1960'lardan sonra başlamıştır. $\mathrm{Bu}$ dönemde köyden kente artan göçlerle beraber kent büyümeye devam etmiş 1969 yılında 1.nolu gecekondu önleme bölgesi olan Aydınlık Evler olarak adlandırılan bölge tahsis edilmiştir. Bu gelişimi 1980'lerde kurulan diğer bir gecekondu önleme bölgesi olan Cumhuriyet Mahallesi izlemiştir. 1990lar ile birlikte Selçuk Üniversitesi yakınına kurulan Bosna Hersek mahallesindeki yapı kooperatifleri ile devam etmiştir. Kent çeperlerine kurulan bu bölgeler ile Konya kentinde gecekondulaşmanın önüne geçilmiş olup alt gelir grubunun konut ihtiyacı karşılanmıştır. Bu ihtiyacı karşılamaya yönelik diğer bir adım ise 2000'lerden sonra TOKİnin kent çeperlerinde yapmış olduğu toplu konutlardır.

Bu çalışma kapsamında yukarıda açıklanmış olan 4 dönemi referans alan bir gruplandırmaya gidilmiştir. Şekil 1'de Konya kentinde seçilmiş olan apartmanların konumları belirtilmiş̧ir. (Son döneme ait 3 örnek kent çeperlerinde oldukları için haritaya işlenmemiştir.) Bu bağlamda öncelikle ilk dönemde yer alan Hayat Apartmanı (1937), Kibrit Apartmanı (1951) ve Ağabeyli Apartmanı (1952) ilk grupta incelenmiştir. Kibrit ve Ağabeyli Apartmanı 1950 yılından sonra yapılmasına rağmen, mekân organizasyonu ve form bakımından 1950 yılı öncesi dönemi yansıtmaktadır. Bu bağlamda ilk grupta değerlendirilmiştir. 1950-1980 yılları arasında Anıt Apartmanı (1964), Horozluhan Apartmanı (1966) ve Karatay Apartmanı (1973) ikinci grupta değerlendirilmiştir. 1980-2002 yılları arasında Karacığan Apartmanı (1988), Site Köşk Apartmanı (1990) ve Sedef Apartmanı (1994) üçüncü grupta incelenmiştir. 2002 yılı sonrası ise dönemdeki farklı konut üretim biçimlerinden seçilen apartmanlar ise Yazır TOKİ (2007), Zermeram (2012) ve Natura Park (2013) değerlendirilmiştir. Bu değerlendirme kapsamında yatak odası odağında Tablo 1-2-3-4'te görülmekte olan analiz tabloları oluşturulmuştur.

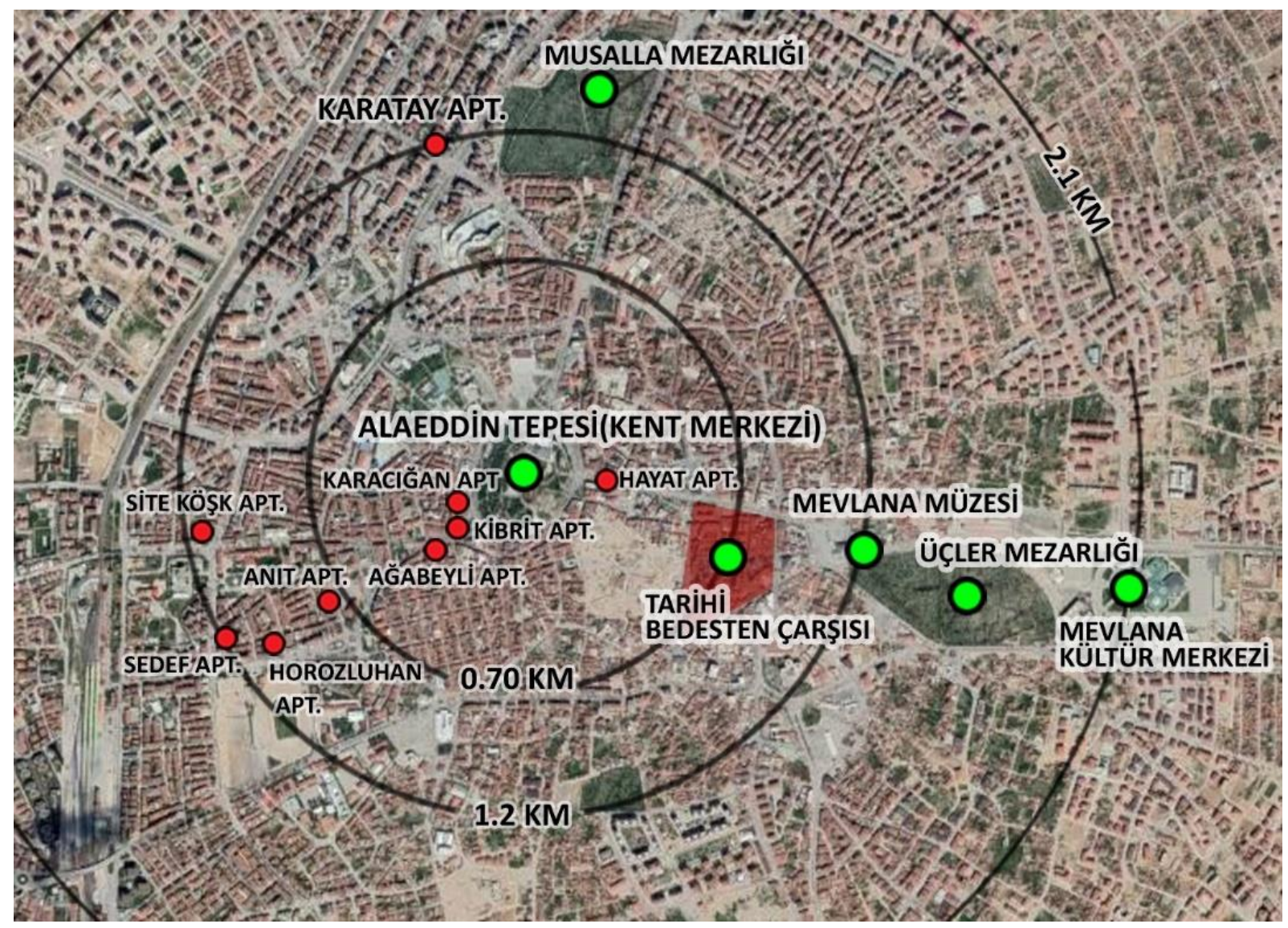

Şekil 1. Seçilen apartmanların Konya kentindeki konumu. 
Tablo1. 1.Dönem (1923-1950) yılları arası seçilen apartmanlar (Tabloda bulunan planlar Süslü (2009)'dan alınmış ve yazarlar tarafından yeniden çizilmiştir.
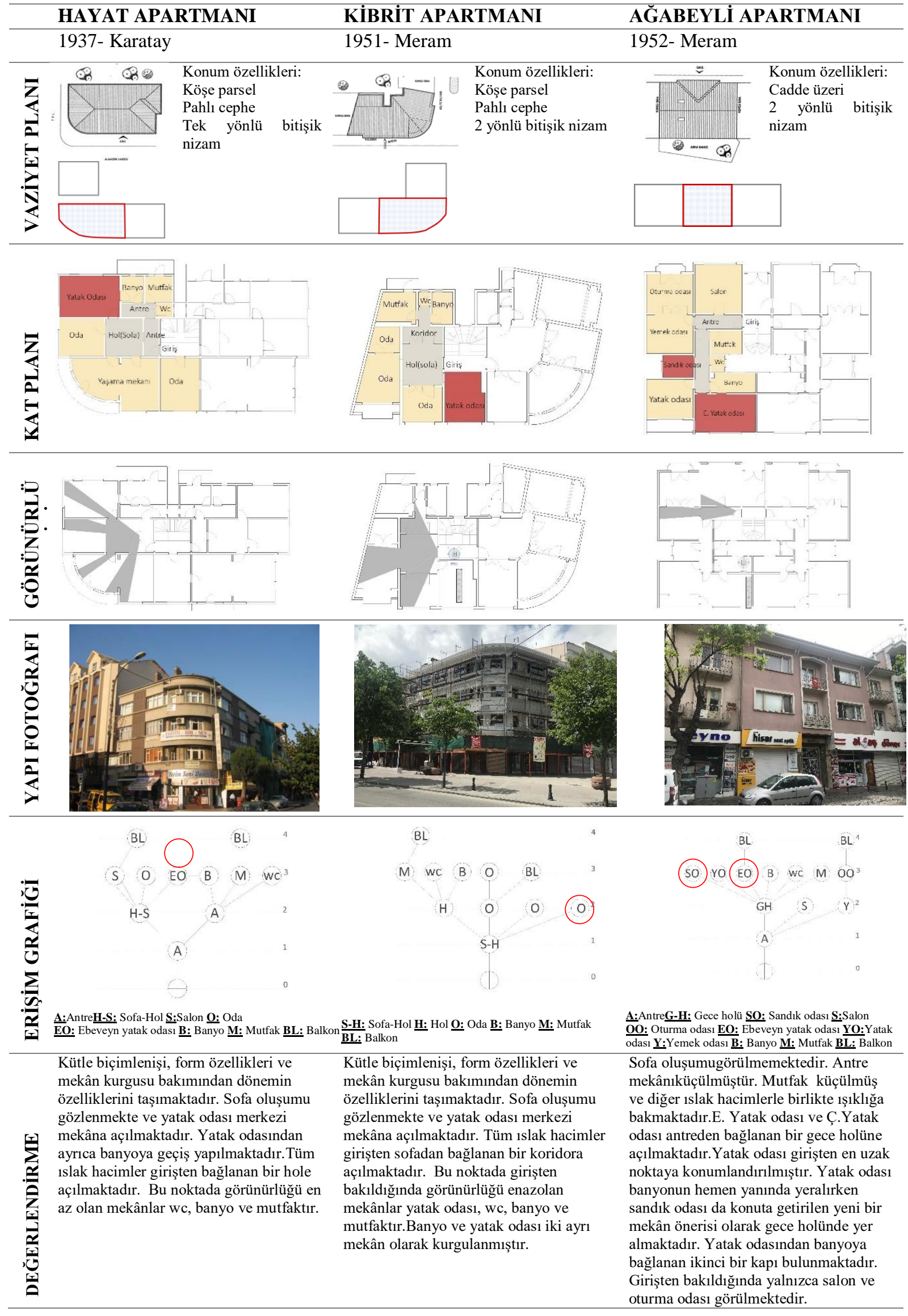

H: Sofa-Hol H: Hol O: Oda B: Banyo $\underline{\text { M: Mutf }}$

Kütle biçimlenişi, form özellikleri ve mekân kurgusu bakımından dönemin zelliklerini tașımaktadır. Sofa olușumu gözlenmekte ve yatak odası merkez açılmaktadır. Tüm sslak hacimler irişten sofadan bağlanan bir koridora maktadir. Bu noktada girișten oturma odası görülmektedir. 
Tablo 2. 2. Dönem (1950-1980) yılları arası seçilen apartmanlar (Tabloda bulunan planlar Süslü (2009)'dan alınmış ve yazarlar tarafından yeniden çizilmiştir.

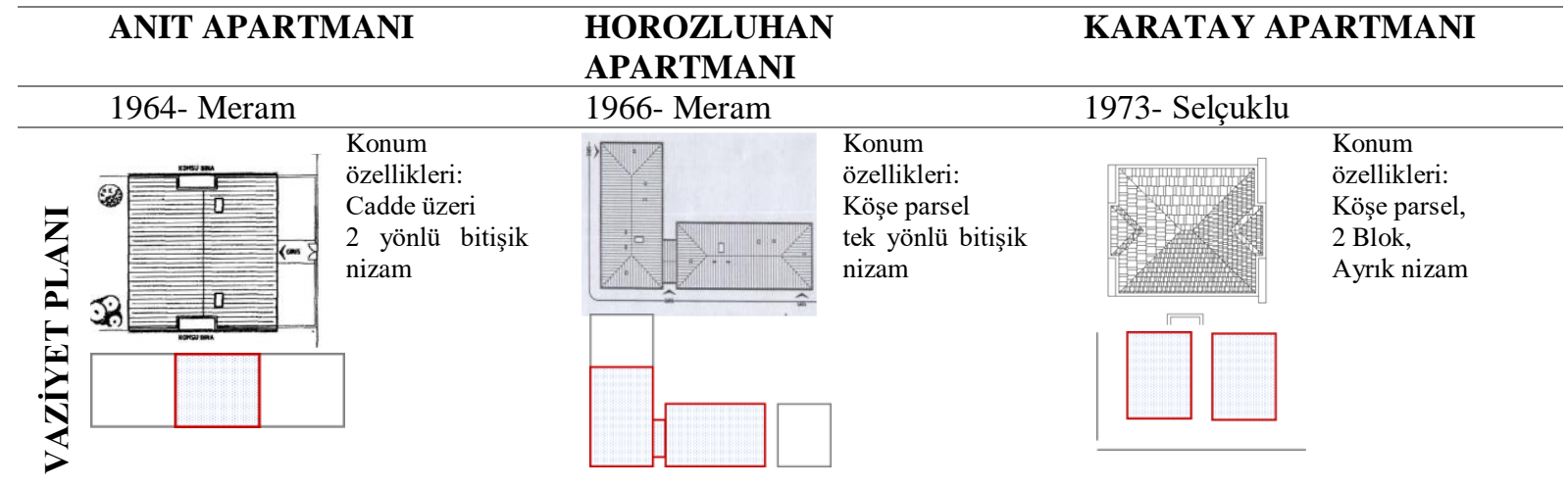
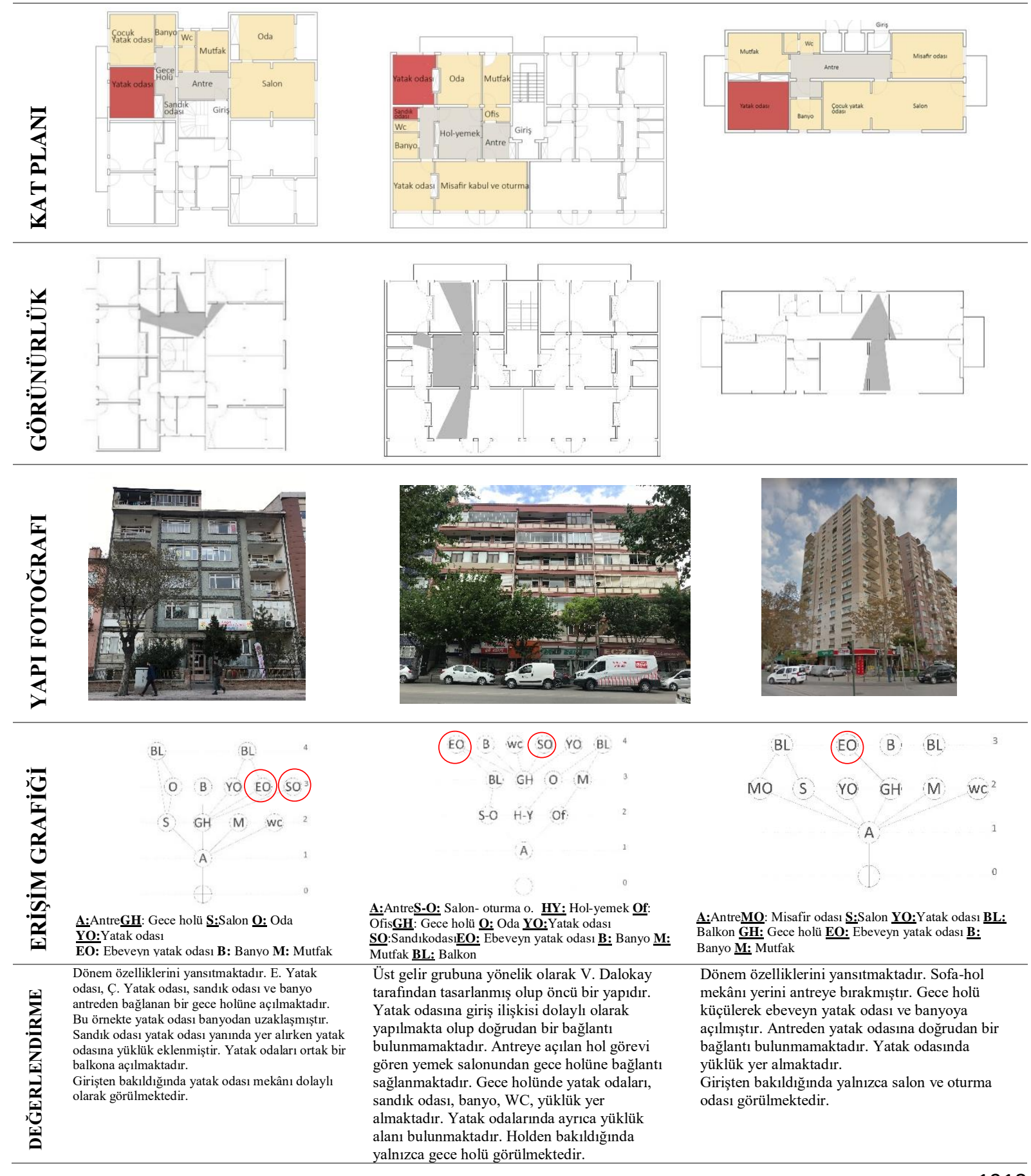
Tablo 3. 3.Dönem (1980-2002) yılları arası seçilen apartmanlar (Tabloda bulunan planlar Süslü (2009)'dan alınmış ve yazarlar tarafindan yeniden çizilmiştir.

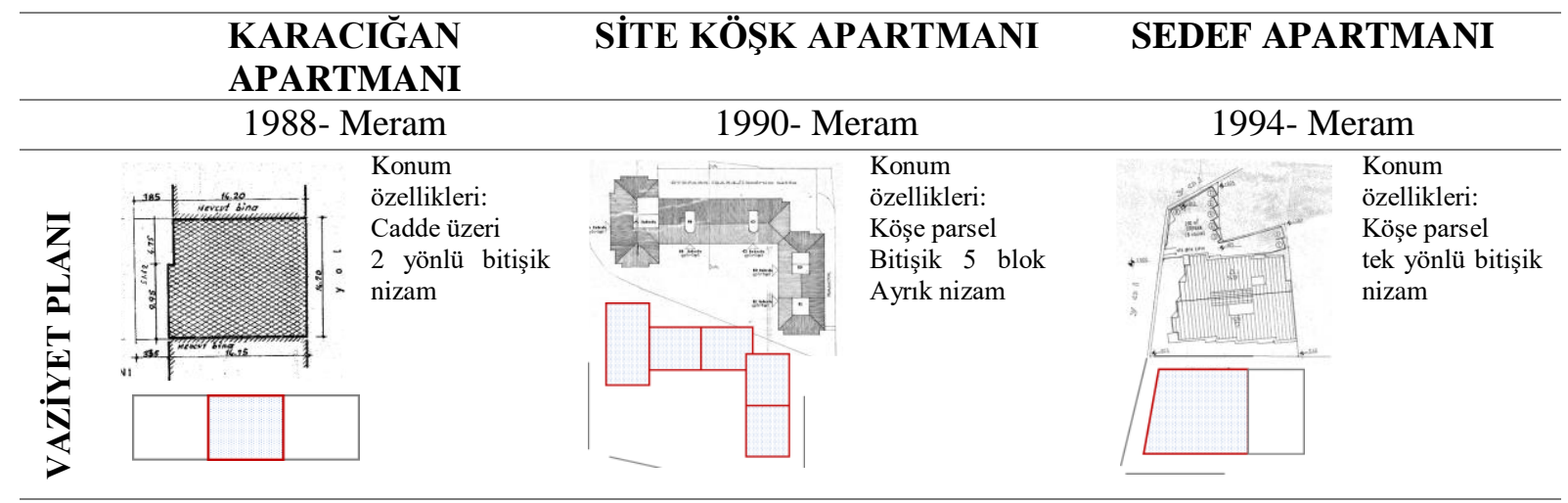
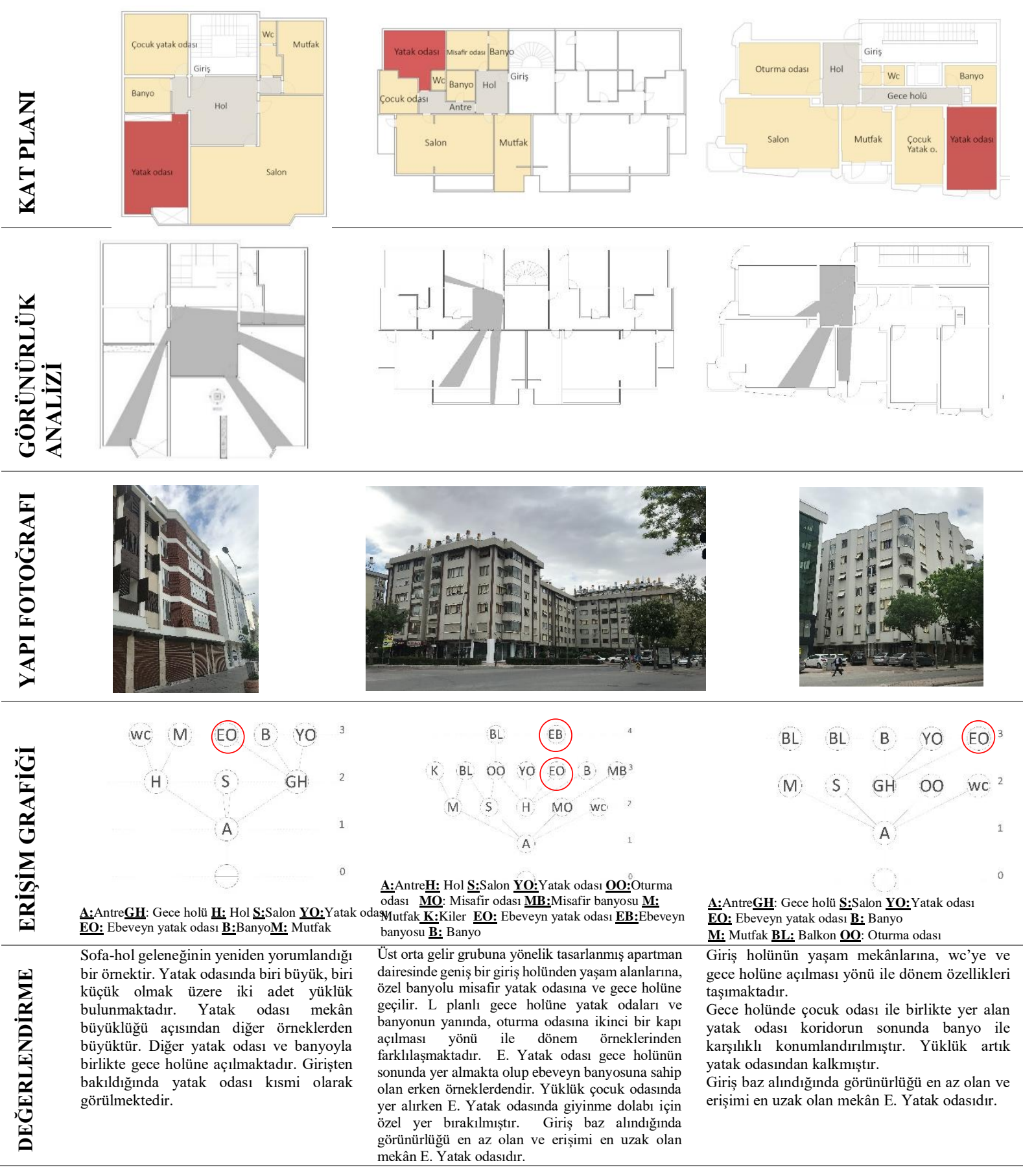
Tablo 4. 4.Dönem (2002 ve sonrası) yılları arası seçilen apartmanlar (Tabloda bulunan planlar Süslü (2009) 'dan alınmış ve yazarlar tarafından yeniden çizilmiştir.

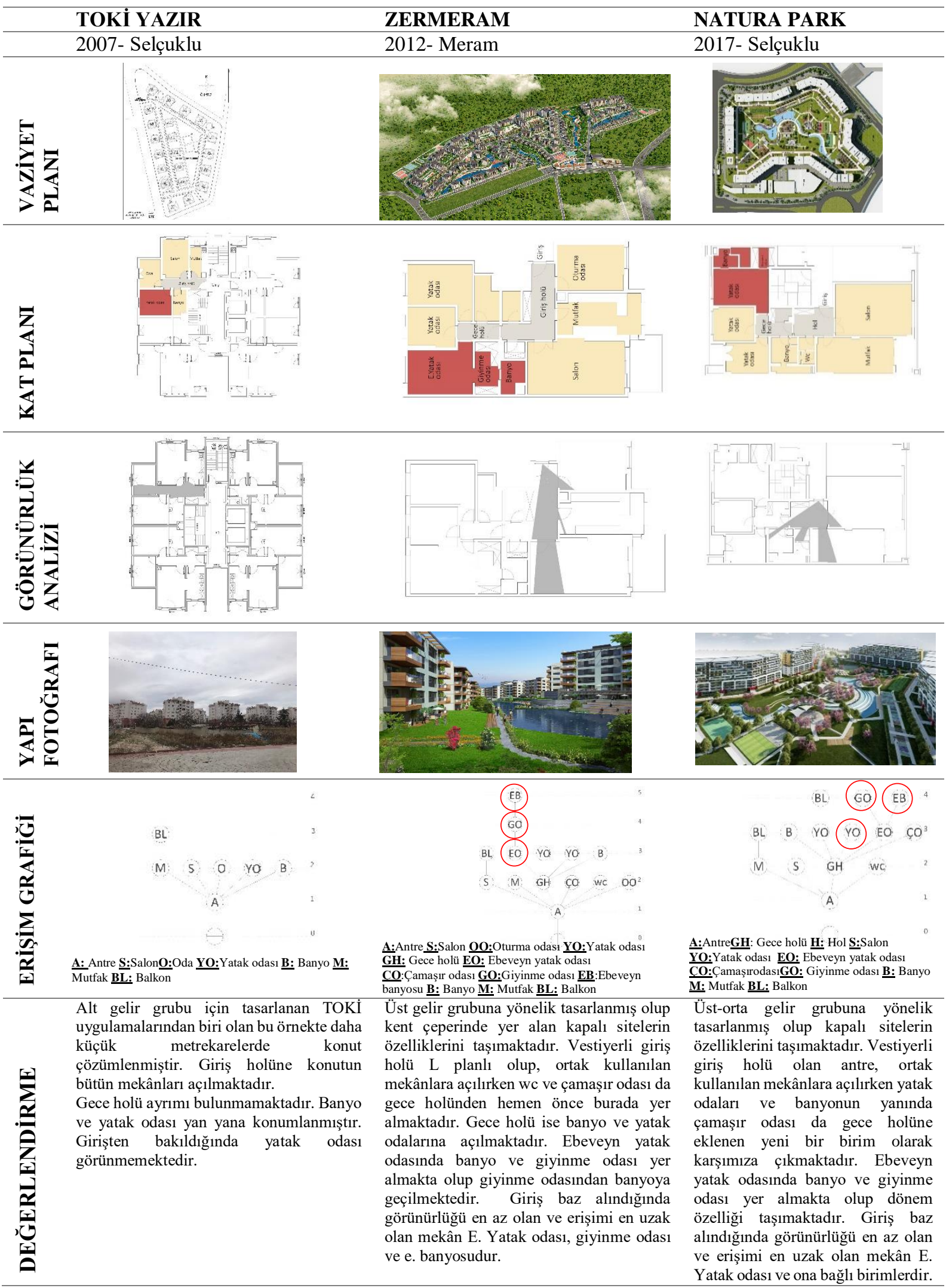




\section{III.BULGULAR}

Çalışma kapsamında incelenen apartman yapıları ait oldukları dönemin özelliklerini gösteren yapılardır. 1923-50 döneminin örneklerinden olan Hayat ve Kibrit Apartmanı, köşe parselde yer almalarından kaynaklı olarak kütle biçimlenişinde dairesel geçişlere başvurulması ve plan kurgusunda merkezi mekân olan sofa/holün etrafında odaların konumlanması bakımından benzer özellikler taşımaktadır. Bu iki örnekte odalar henüz özelleşmemiştir ve yatak odasına sofadan giriş yapılmaktadır. Islak hacimlere ise Hayat Apartmanı'nda antreden, Kibrit Apartmanı'nda ise sofadan açılan ayrı bir hol üzerinden bağlanılmaktadır. Hayat Apartmanı'nda yatak odasından banyoya ikinci bir kapı açılması döneminde başvurulan bir uygulamadır ve Güney'in ifadesine göre bu uygulama Türk odasındaki gusülhane alışkanlığının yeni bir yorumudur [36]. Kibrit apartmanı ise yatak odası ve banyo ilişkisinin en dolaylı kurulduğu örnek olarak karşımıza çıkmaktadır. Döneme ait bir diğer örnek olan Ağabeyli apartmanı ise ilk iki örnekten ayrılarak sofa yerine antreli bir giriş ve ona eklenen ıslak hacimler ile yatak odalarının yer aldığı bir gece holünden oluşmaktadır. Yalnız buradaki gece holü tam anlamını karşılamamakta olup wc, mutfak ve yaşam alanının bir diğer kapısının açıldığı bir ara mekândır. Yatak odası banyo ile yan yana konumlanmış olup Hayat Apartmanı'nda olduğu gibi yatak odasından ikinci bir kapı da ayrıca açılmıştır. Bu örnekle birlikte mekânlar özelleşmeye başlamış yatak odalarına yakın konumlanan sandık odası yeni bir saklama mekânı olarak karşımıza çıkmış, ikinci bir sirkülasyon mekânının varlığı ile yatak odasının hem görünürlüğü azalmış hem de mekân derinlik değeri artmıştır.

1950-80 dönemindeki ilk örneklerden olan Anıt Apartmanı gece holü kavramının oluştuğu bir örnek olup yaşam alanları ve ortak mekânların, yatak odalarından ayrı tutulması açısından önemlidir. Gece holünde yatak odaları ile banyo ve sandık odası yer alırken artık odalarda yüklükler de görülmektedir. Dönem yapılarından Horozluhan apartmanı ise farklılaşan bir örnektir. Dönemin üst gelirli aileleri için mimar Vedat Dalokay tarafından tasarlanan yapı 40 daireden oluşmaktadır ve dairelerin metrekareleri ile oda sayıları dönemdaşlarına göre fazladır. Bu örnekte mutfak girişe yakınlaşmış ve mutfak önüne ofis mekânı eklenmiştir. Giriş bir antreye açılmakta ve oradan ulaşılan yemek odası olarak tanımlanan bir hol sofa görevi görmektedir. Bu orta hole bağlanan bir gece holü de ayrıca eklenmiştir. Gece holü, banyo, wc, sandık odası ve yüklüklü iki yatak odasına açılmaktadır. Horozluhan apartmanı, kullanıcının isteklerini karşılayan özel mekânların yer aldığı, sofa etkisinin devam ettiği ancak konut planında yeniliklerin de gözlendiği bir geçiş yapısı olarak değerlendirilebilir. Bu örnekte yatak odasının derinlik değeri artmıştır. Karatay Apartmanı dönemdeki kooperatif üretiminin bir örneği olup burada konut metrekarelerinin küçüldüğü gözlemlenmektedir. Burada ana sirkülasyon mekânı büyümüş gece holü ise küçülerek yalnız yatak odası ve banyonun açıldığı özel bir ara mekân olmuştur. Sandık odası kalmış, yüklükler ise iki yatak odasında da görülmektedir.

1980-2002 dönemi içerisinde değerlendirilen Karaciğan apartmanı plan şema olarak erken dönem örneklere benzemektedir. Sofa-hol oluşumunun gözlemlendiği bu örnekte gece holü de bulunmakta olup bu mekâna açılan yatak odası konut içindeki büyülük oranı en fazla olan örnektir. Yatak odasında farklı boyutlarda iki yüklük bulunması biri büyük olan yüklüğün sandık odası olarak değerlendirilmiş olabileceğini düşündürmektedir. Bir diğer örnek olan Köşk Apartmanı'nın -kapalı otoparkıyla, dairelerin büyüklügü ve içerisinde yer alan özel banyolu bir misafir odasiyla, banyolu olan geniş metrekareli ebeveyn yatak odasıyla, kilerli mutfağıyla- 2000lerden sonra kentte tercih edilen $4+1$ olarak adlandırılan konut tipinin öncül bir örneği olduğu söylenebilir. Yüklük ebeveyn yatak odasında kalkarken çocuk yatak odasında görülmektedir. Köşk Apartmanı bulunduğu dönem içerisindeki örneklere göre yatak odası mekân derinliği bakımından daha yüksek bir değere sahiptir. Sedef Apartmanı ise dönemin oturma odalı $3+1$ olarak adlandırılan konut tipinin tipik bir örneğini yansıtmakta olup yatak odalarında artık yüklük görülmemektedir.

2002 sonrası örnekler içerisinde TOKİ uygulaması olan yap1, en küçük metrekareye sahip olup gece holünün görülmediği, yatak odası ile ilişkili özel mekânların bulunmadığı ve yatak odasının banyoya en yakın mekân olarak konumlandırıldığı bir örnektir. Üst ve orta gelir grubuna yönelik olan Zermeram ve Natura Park konutları günümüz kapalı sitelerinin bir temsili olup Konya kentinde talep edilen, emlak sektöründe $3+1,4+1$ daire olarak lanse edilen içerisinde ihtiyaca yönelik özelleşmiş mekânlar barındıran 
örneklerdir. Bu iki örnek de benzer mekân kurgusuna sahip olup çamaşır odası gibi yeni birimlerin yanında yatak odasında giyinme odası ve ebeveyn banyosunun da yeni bir destekleyici mekân olarak karşımıza çıktığı görülmektedir. Bunun yanında yatak odası ve ona bağlı mekânların derinliği artmıştır.

Şekil 2'de görüldüğ̈̈ üzere tüm konutların büyüklük analizi yapılmıştır. Bu noktada Karacığan apartmanı hem dönemdaşlarına göre hem de tüm dönemlere göre büyüklük açısından farklı bir noktadadır. Diğer konut örneklerinde ise genel bir bakış açısıyla bakıldığında yatak odası büyüklüklerinin toplam konut büyüklüğüne oranının \%15-18 aralığında olduğu tespit edilmiştir.

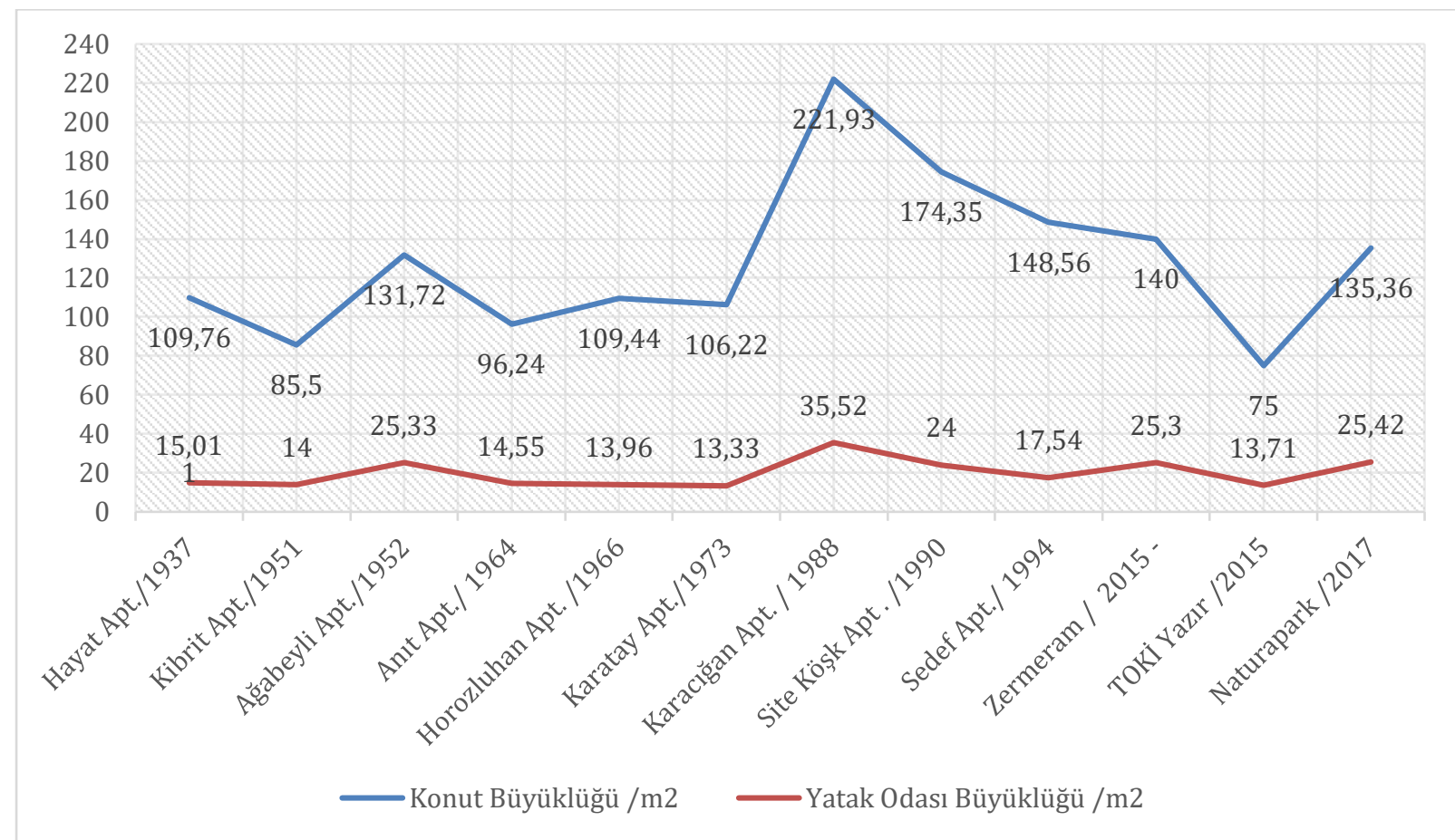

Şekil 2. Toplam konut büyüklüğü ile yatak odası büyüklüğü ilişkisi.

\section{TARTISMA VE SONUC}

Tanzimat ile başlayan Cumhuriyetin ilanı ile devam eden Türkiye'deki modernleşme süreci Türk aile yapısında değişime yol açmış ve bu değişim konutlara da yansımıştır. Geleneksel, ataerkil, geniş ailelerin yerini çekirdek aileler alırken çok fonksiyonlu odalara ve sabit donatılara sahip konakların yerini de özelleşmiş mekânlanı ve o mekânlar için tasarlanmış mobilyaları olan apartman daireleri almıştır. Sanayileşme ile kırdan kente artan göçler kentlerdeki nüfusun artmasına neden olmuş bundan ötürü hızla artan konut ihtiyacını karşılamaya yönelik uygulamalar Türkiye'deki konut yelpazesini genişletmiştir. Bu çalışmada ülkemizdeki konut politikalarına göre tanımlanmış dört dönem içerisinde konut payının büyük çoğunluğuna sahip olan apartmanlar ve bu yapı tipinin farklı örnekleri yatak odası özelinde Konya kenti üzerinden değerlendirilmiştir. Tablo 6'da değerlendirmeye konu olan kriterler doğrultusunda bir çizelge hazırlanmıştır. Buna göre ilk dönem örnekleri geleneksel plan şemanın devamı niteliğinde olan sofa ve ona bağlı odalardan oluşan bir kurgu olup banyonun ayrı bir holde yer aldığ1 ancak bazı örneklerden ikinci bir kapının yatak odasından açıldığı anlaşılmaktadır. Bu dönem örneklerde yatak odasının derinlik derecesi düşüktür. Bundan dolayı ilk dönem örneklerinin sunduğu mekânsal mahremiyetin sonraki dönemlere göre daha az olduğu görülmektedir. Daha sonraki dönemde gece holü ayrımı oluşmaya başlandığı görülmekte olup sandık odası ve yüklük uygulamaları ile yatak odası mekânı desteklenmiştir. Bu örneklerde artık banyo gece holünde yer alırken yatak odasından kapı ile banyoya bağlanma durumu da görülmemektedir. 1980 sonrası dönemin ilk örneklerinde yatak odasında yüklük gözlemlenirken sonraki dönemde kalkmıştır. Yatak odası, banyo ile gece holünde yer alırken ebeveyn banyosu kullanımının ilk örneği de yine bu dönemde görülmektedir. Günümüze bakıldığında ise alt gelir grubuna yönelik toplu konut uygulamaları istisna tutulursa kentteki apartman yapılarında 
ebeveyn yatak odasının gece holünde diğer yatak odaları, banyo ve çamaşır odası gibi mekânlarla birlikte yer aldığı görülmekte olup yatak odasının giyinme odası, duş ya da özel banyo gibi birimlerle desteklendiği ve konut içindeki büyüklüğü ile mekân derinliğinin arttığı gözlemlenmektedir.

Değişen ihtiyaçlar, modern insanın artan tüketimi, kalorifer sistemleri ve konutlardaki 1sıtma probleminin azalması, buna bağlı olarak çekirdek aileye yönelik konutlarda metrekarelerin büyümesi ve ihtiyaca yönelik özelleşmiş mekânların ortaya çıkmasında etkili olmuştur. İlk dönem örneklerinde mekânlar oda olarak tanımlanırken bir sonraki dönemde yatak odası birimi ayrılmaya başlanmış, daha sonraki süreçte çocuk odası da bu ayrıma eklenerek bireyselleşmenin konut içine etkisi görülmüştür. Bu noktada, süreç içerisinde toplumsal yaşama göre biçimlenen Türk tipi apartmanlaşmada konut içi özelleşmiş mekânların organizasyonunda antre, gece holü gibi ara mekânlar mahremiyet denetimini sağlayan geçiş mekânları olarak önemli bir yer tutmaktadır. Yatak odasının da bu geçiş mekânlarından en son ulaşılan yer olarak karşımıza çıkmasında konut içi mahremiyet denetim mekanizmasının süreç içindeki işleyişinin göstergesinin yanında toplumsal yaşam biçiminin konuta kazandırdığı ifade olarak da yorumlanabilmektedir. Bu bağlamda Güney, yatak odası mekânın oluşumunu Türkiye'de davranış biçimlerinde en zorlu değişimlerden biri olduğunu ifade etmiş, gündüz yüklüklerde saklanan yatak ve yorganların sürekli görünür hale gelmesine alışmanın kolay olmadığını Osmanlı döneminde batıdan ithal edilen karyolaların önüne paravan eklenmesi durumuyla örneklendirmiştir [36]. Geleneksel Türk odasındaki gusulhane ve yüklük, erken dönemlerde sandık odası ve yüklük olarak karşımıza çıkarken bugün yatak odalarında giyinme odası ve ebeveyn banyosu olarak karşımıza çıkması ise kültür kodlarının devamlılığı olarak yorumlanabilmektedir. Bu çalışma yatak odası mekânı üzerinden kültürün modern yaşama entegrasyonuna örnek olarak gelecek çalışmalara bir kapı açmaktadır.

Tablo 6. Seçilen apartmanların belirlenen parametreler doğrultusunda değerlendirilmesi.

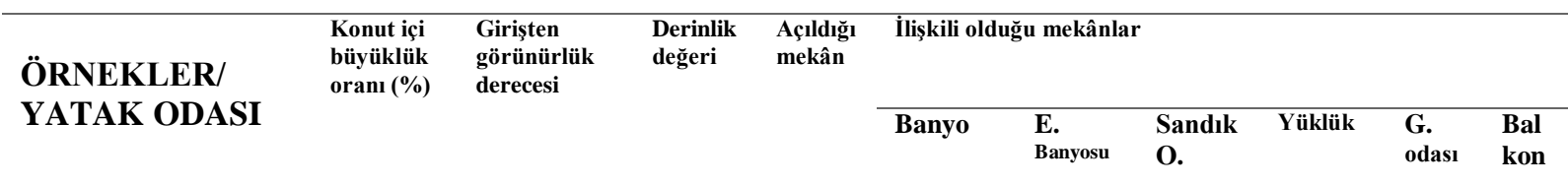

\begin{tabular}{|c|c|c|c|c|c|c|c|c|c|c|c|}
\hline \multirow{3}{*}{ 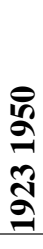 } & Hayat Apt. & $\% 13,68$ & Kismi & 3 & Sofa & $\begin{array}{l}\text { F.H. } 2 . \\
\text { kap1 }\end{array}$ & - & 一 & 一 & 一 & 一 \\
\hline & Kibrit Apt. & $\% 16,37$ & Yok & 2 & Sofa & F.H. & - & 一 & 一 & 一 & 一 \\
\hline & $\begin{array}{l}\text { Ağabeyli } \\
\text { Apt. }\end{array}$ & $\% 19,23$ & Yok & 3 & $\begin{array}{l}2 . \\
\text { Hol }\end{array}$ & $\begin{array}{l}\text { A.H. } 2 . \\
\text { kap1 }\end{array}$ & - & $\checkmark$ & 一 & 一 & $\checkmark$ \\
\hline \multirow{3}{*}{$\begin{array}{l}\stackrel{8}{\circ} \\
\frac{8}{2} \\
\frac{\ln }{2}\end{array}$} & Anit Apt. & $\% 15,11$ & Dolaylı & 3 & $\begin{array}{l}\text { Gece } \\
\text { holü }\end{array}$ & A.H. & - & $\checkmark$ & $\checkmark$ & 一 & $\checkmark$ \\
\hline & $\begin{array}{l}\text { Horozluhan } \\
\text { Apt. }\end{array}$ & $\% 12,75$ & Dolaylı & 4 & $\begin{array}{l}\text { Gece } \\
\text { holü }\end{array}$ & A.H. & - & $\checkmark$ & $\checkmark$ & - & $\checkmark$ \\
\hline & Karatay Apt. & $\% 12,54$ & Yok & 3 & $\begin{array}{l}\text { Gece } \\
\text { holü }\end{array}$ & A.H. & - & 一 & $\checkmark$ & 一 & 一 \\
\hline \multirow{3}{*}{ 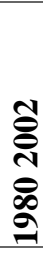 } & $\begin{array}{l}\text { Karaciğan } \\
\text { Apt. }\end{array}$ & $\% 16$ & Kismi & 3 & $\begin{array}{l}\text { Gece } \\
\text { holü }\end{array}$ & A.H. & - & 一 & $\checkmark$ & - & 一 \\
\hline & $\begin{array}{l}\text { Site Köşk } \\
\text { Apt. }\end{array}$ & $\% 13,76$ & Yok & $3-4$ & $\begin{array}{l}2 . \\
\text { Hol }\end{array}$ & A.H. & $\checkmark$ & 一 & 一 & - & 一 \\
\hline & Sedef Apt. & $\% 11,81$ & Yok & 3 & $\begin{array}{l}\text { Gece } \\
\text { holü }\end{array}$ & A.H. & - & 一 & 一 & 一 & - \\
\hline \multirow[b]{3}{*}{ ๙ิ่ } & Yazır TOKİ & $\% 18,28$ & Yok & 2 & $\begin{array}{l}\text { Giriş } \\
\text { holü }\end{array}$ & A.H. & 一 & 一 & 一 & 一 & 一 \\
\hline & Zermeram & $\% 18,07$ & Yok & $3-5$ & $\begin{array}{l}\text { Gece } \\
\text { holü }\end{array}$ & A.H. & $\checkmark$ & - & 一 & $\checkmark$ & 一 \\
\hline & Natura Park & $\% 18,77$ & Yok & $3-4$ & $\begin{array}{l}\text { Gece } \\
\text { holü }\end{array}$ & A.H. & $\checkmark$ & 一 & 一 & $\checkmark$ & 一 \\
\hline
\end{tabular}

Kısaltmalar: $\quad$ A.H. : Aynı holde yer alıyor. $\quad$ F.H. : Farklı holde yer alıyor. 
Yukarıdaki verilerden hareketle Türkiye'de konut politikaları bağlamında irdelenen apartman tipi yapıların gelişim süreci; cumhuriyet ile birlikte yoğunlaşan batılılaşma ve çağdaş yaşama entegrasyon faaliyetlerine, endüstrileşme sürecine, değişen siyasi yapıya, yaşam biçimine ve aile yapısındaki değişime göre ifade kazanmıştır. Tanyeli'nin ifadesiyle 1970lerde konut gereksinimi hiç bitmeyecekmiş izlenimi veren ülke birkaç on yılın ardından, bugün konut arzı fazlasıyla karakterize olmuştur. Bunun sonucunda konut artık bir yatırım nesnesine dönüşmüş, barınma ekonomi gerçekliğine indirgenmiştir. Konut reklamcıların, pazarlamacıların, iktisatçıların, kredi kurumlarının ve yatııımcıların diline persenk olmuş, mimarlar ise konuta tasarım ve marka değeri katan aktörlere dönüşmüştür [37]. Bugünün Türkiye'sinde artık konut marka değeri ile orta ve üst gelir grubu için bir prestij imgesine, talep fazlası durumu ile de alınıp-satılan, üzerinden kar edilen bir metaya dönüşmüştür. Yatak odası mekânı da bu metanın pazarlanma stratejilerinden birine dönüşmüş, gerek konutun barındırdığı yatak odası sayısı ile gerek ebeveyn yatak odası ve onu diğer odalardan özelleştiren destek mekânlarıyla konut tercih ediniminde dikkate alınan bir unsur olmuştur.

\section{KAYNAKLAR}

[1] Encyclopaedia Britannica. (2020, 7 Eylül). Apartment house. [Online]. Erişim:http://www.britannica.com/technology/apartment-house

[2] Anonim, "Apartman, çok katlı kolektif konut, bir görsel belgeleme," Arrademento Mimarlı Dergisi, s. 4, ss. 48-56, 2007.

[3] A. Stevenson, "Apartment," Oxford Dictionary of English, 3. bask1, Oxford, UK: Oxford University Press, 2010, ss. 521.

[4] Dictionnaire de Français Larousse. (2020, 7 Eylül). Appartement. [Online]. Erişim: http://www.larousse.fr/dictionnaires/francais/appartement/4651?q=appartement\#4632

[5] T. Görgülü, 'A Apartman tipolojisinde geçmişten bugüne; kira apartmanından "Rezidans'a Geçiş," TÜBA-KED, s. 14, ss. 165-178, 2016.

[6] U. Tanyeli, İstanbul 1900-2000 Konutu ve Modernleşmeyi Metropolden Okumak, 1. bask1, İstanbul, Türkiye: Akın Nalça Kitapları, 2004, ss. 25.

[7] G. P. Gökmen, “Türkiye'de apartmanlaşma süreci ve konut kültürü,” Güney Mimarlı, s. 5, ss. 12-16, 2011.

[8] S.H. Eldem, Türk Evi Plan Tipleri, 1. Bask1, İstanbul, Türkiye: İstanbul Teknik Üniversitesi Mimarlık Fakültesi Yayınları, 1954, ss. 25.

[9] A. D. Öncel, Apartman-Galata'da Yeni Bir Konut Tipi, 1. bask1, İstanbul, Türkiye: Kitap Yayınevi, 2010, ss.263.

[10] D. Demirarslan, "Osmanlı'da Modernleşme/ Batılılaşma Sürecinin İç Mekân Donanımına Etkileri”, Erdem, c.16, s. 45-46-47, ss. 35-66, 2006.

[11] M. Akalın, "Sosyal konutların Türkiye'nin konut politikaları içerisindeki yeri ve Toki’nin sosyal konut uygulamaları," Firat Üniversitesi Sosyal Bilimler Dergisi, c. 26, s. 1, ss. 107-124, 2016.

[12] Y. Sey, "Cumhuriyet Döneminde Konut," Bilanço'98 75 Yılda Değişen Kent ve Mimarlık, 1. bask1, İstanbul, Türkiye: Tarih Vakf1, 1998, ss. 273-300. 
[13] A. Çoban, "Cumhuriyetin ilanından günümüze konut politikası," Ankara Üniversitesi SBF Dergisi, c. 67, s. 03, ss. 75-108, 2012.

[14] N. Bayraktar, "Bonatz'ın Türk Evi Sevgisinin Biçimsel Aktarımı: Saraçoğlu (Namık Kemal Mahallesi)", Arredemento Mimarlık, s.06, ss. 66-74, 2011.

[15] R. Keleş, Kentleşme Politikası, 14. bask1, Ankara, Türkiye: İmge Kitabevi, 2015, ss. 422-485.

[16] E. Akcan, Çeviride Modern Olan - Şehir ve Konutta Türk-Alman İlişkileri, 1. Baskı, İstanbul, Türkiye: Yapı Kredi Yayınları, 2009, ss. 228-241, 314, 363.

[17] İ. Tekeli, Konut Sorununu Konut Sunum Biçimleriyle Düşünmek, 1. bask1, İstanbul, Türkiye: Tarih Vakfi Yurt Yayınları, 2009, ss. 178.

[18] A. Batur, "Modern Mimarlık Hareketinin Mimarlık Yayınlarında Ele Alınışı ve Yayınların Uygulamaya Etkisi”, Mimarlık, s.215-216, ss.35-38, 1985.

[19] S. Bozdoğan, Modernizm ve Ulusun İnşast: Erken Cumhuriyet Türkiye'sinde Mimari Kültür, 1. bask1, İstanbul, Türkiye: Metis Yayınları, 2002, ss: 203, 322.

[20] İ. Aslanoğlu, Erken Cumhuriyet Dönemi Mimarlığı (1923-1938), 3. bask1, İstanbul, Türkiye: Bilge Kültür Sanat, 2010, ss. 79-81.

[21] E. B. Findıkl1, "Millilik, mobilya ve zevk terbiyesi: mimar ve dekoratörlerin mobilya üzerine sürdürdükleri tartıșmalar (1931-1950)," Tarih Okulu Dergisi (TOD), s. 32, ss. 87-114, 2017.

[22] U. Tanyeli, “Konut Mekânında Modernite Kavgası” Mimarlık, s. 262, ss. 16-18, 1995.

[23] S. Bozdoğan, “Türk Mimari Kültüründe Modernizm: Genel Bir Bakiş,” Türkiye'de Modernleşme ve Ulusal Kimlik, 3. baskı, İstanbul, Türkiye: Tarih Vakfı Yurt Yayınları, 1998, ss. 190217.

[24] D. Koca, “Türkiye'de çağdaş konut üretiminin yeniden okunması," Tasarım + Kuram, c. 11, s. 19, ss. 19-36, 2015.

[25] S. F. Büyükçam, "Türk evinden apartmana Türkiye'de konut olgusu; 1950-1980 dönemi İstanbul apartmanları," Dicle Üniversitesi 1. Uluslararası Mimarlık Sempozyumu, Diyarbakır, Türkiye, 2018, ss. 64-78.

[26] M. Yenice, "Türkiye'nin kentsel dönüşüm deneyiminin tarihsel analizi," Balıkesir Üniversitesi Fen Bilimleri Enstitüsü Dergisi, c. 16, s. 1, ss. 76-88, 2014

[27] T. Görgülü ve S. K. Koca, "Türkiye'de barınma biçimlerinde yaşanan değişimler: son dönemde yapılan tüketim odaklı konutlar”, Mimarlık, s. 337, ss. 29-33, 2007.

[28] M. Akalın, "Mekânsal Ayrışmanın Bir Yeni Biçimi Olarak Kapalı Siteler Akkent Konutları Örneği", Hitit Üniversitesi Sosyal Bilimler Enstitüsü Dergisi, c. 9, s. 2, ss. 923-956, Ara. 2016, doi:10.17218/hititsosbil.280823

[29] T. Görgülü, "İstanbul'da çeşitlenen konut üretim biçimleri ve değişen konut alışkanlıkları", Mimarist, s. 7, ss. 50-56, 2003.

[30] B. Hillier ve J. Hanson, The Social Logic of Space, Londra, UK: Cambridge University Press, $1984,147-155$. 
[31] M. Benedikt, "To Take the Hold of Space: Isovists and Isovist Fields", Environment and Planning B, c. 6, s.1, ss. 47-65.

[32] C. Berk, Konya Evleri, 1. bask1, İstanbul, Türkiye: İstanbul Matbac1lık, 1951, ss. 46-48.

[33] M. Ulusoy ve H. E. Ulusoy, "Kültürel değişim bağlamında konut; Konya örneği, ” Artium, c. 3, s. 1, ss. 30-38, 2015.

[34] M. Ulusoy, Konya'da Apartman Yapılarının Tarihi Gelişimi, 1. baskı, Konya, Türkiye, 2006, ss. 43-44, 213-216.

[35] Ş. Süslü, "Konya'da apartman yapılarının tarihi süreç içinde cephe özelliklerinin gelişimi," Yüksek lisans tezi, Mimarlık, Fen Bilimleri Enstitüsü, Selçuk Üniversitesi, Konya, Türkiye, 2009.

[36] Y. İ. Güney, "Konutta mekânsal organizasyon ve toplumsal cinsiyet: yirminci yüzyıl Ankara apartmanları," Cins Cins Mekân, 1. baskı, İstanbul, Türkiye: Varlık, 2009, ss. 102-135.

[37] U. Tanyeli, Yıkarak Yapmak: Anarşist Bir Mimarlık Kuramı İçin Altlık, 1. baskı, İstanbul, Türkiye: Metis Yayınları, 2017, ss: 341-342. 